\title{
THE SYSTEM OF AGRARIAN LOGISTICS: DEFINITION, MAIN TASKS AND CONDITIONS OF ITS FUNCTIONING
}

\author{
Tetiana Chaika, Tetiana Voronko-Nevidnycha, Ilona Yasnolob, Oleksii Zoria \\ Poltava State Agrarian Academy, Ukraine
}

\begin{abstract}
The article deals with the problem of the definition of the term "logistics". It describes the main functional spheres and the tasks of logistics of agrarian enterprises. The authors define the distinctive features of marketing and logistics and prove the urgency of the introduction of both conceptions with the purpose of the optimization of selling activity of agrarian enterprises. The article offers the model of the system of agrarian logistics including crop growing, livestock breeding, fishing and bee keeping logistics with a detailed classification of branches according to the main types of products. The authors describe the factors of the influence of the selling process in agriculture on the system of logistics with the aim of adaptation to the specific character of agrarian enterprises.
\end{abstract}

Keywords: logistics, introduction, management, agrarian enterprise, purchase, sales, production

DOI: $10.17512 /$ znpcz.2016.1.07

\section{Problem statement}

Since Ukraine has become a member of WTO and because of the country's integration to the world food market, national producers have faced with a problem of raising their competitiveness. Agrarian producers also have to adapt to the conditions of international competitive environment. These problems and the necessity to provide national food security require the introduction of new and more effective methods and technologies into the process of agrarian enterprises management which can improve the level of development of agriculture as well as enable to gain a market share in international environment. In this context much attention is given to such methods of optimization of economic activity that can provide synergic effect in the process of interaction of economic entities with other participants in the chains of promotion of agrarian products. In these conditions we consider the concept of logistics to be the most efficient. This concept is quite widespread in world practice, but relatively new for Ukrainian management instrumentation.

\section{The analysis of the latest research and publications}

The problems of logistics in organizing the process of selling are researched in a large number of works by such foreign and national authors as: B. Anikin, J. Bolt, O. Hadzhynskyi, O. Hirna, M. Edous, A. Kalchenko, I. Krykavskyi, M. Meskon, L. Moroz, I. Nerush, M. Oklander, O. Khromov, A. Chudakov, 
N. Chukhrai etc. At the same time, a lot of questions concerning the usage of logistic approach in the process of selling products of agrarian enterprises are still not fully studied.

\section{The objective of the research}

The objective of the article is to describe the role of logistics in the process of selling products of agrarian enterprises taking into account their peculiarities.

\section{The main part of the research}

The idea of application of logistics in business administration emerged only in 1970s although this term appeared in Ancient Greece meaning the art of making payments (Родников 2000, p. 352). In general, logistics was developing in three trends, such as military, mathematical and economical, with the first trend being the most recognized. Since logistics can be applied in various spheres, there are different approaches to the definition of this term. In our opinion, this fact and the relative novelty of the economic trend in logistics were the reasons for the late introduction of this concept into the national categorical apparatus of economic terms. For instance, in Ukraine it began to be used in the early 1990s both in special books and mass media meaning the theory and practice of management of tangible and information flows (Крикавський, Чухрай, Чорнописька 2006, p. 340). However, nowadays there is no generally accepted definition of the term logistics even in its economic aspect and its objects and tasks are not clearly determined.

For instance, T. Skorobohatova defines logistics as the science of management of tangible and information flows in a certain system (Скоробогатова 2005, p. 116). However, we consider this definition to be incomplete as it does not give the detailed information about the area of application of logistics and does not focus on its importance. The similar definition is given by T. Kosarieva who thinks that logistics is the science and practice of management of flow processes (Косарева 2008, pp. 12-19).

The more substantial definition is given by O. Trydid, H. Azarenkova, S. Mishyna and I. Borysenko. In their opinion, logistics is the science about the optimal management of tangible, information, and financial flows in economic adaptive systems with synergic relations (Тридід, Азаренкова, Мішина, Борисенко 2008, p. 566). This definition describes the area of application and the object of logistics, but the word combination "synergic relations" needs a more detailed explanation. In addition to it, the availability of these relations in the economic system does not stipulate the application of logistics, although the introduction of logistics facilitates these relations to appear.

O. Hutorov, O. Lebedynskyi, N. Prozorova, U. Albekov, V. Fedko and O. Mytko consider logistics to be a science. They define logistics as the science about the planning, control and management of transportation, storage and other tangible and intangible operations which appear in the process of transporting of raw materials to manufacturing enterprises, processing of raw materials, stuff and 
semi-finished products and delivery of finished products to customers according their interests and requirements as well as the transferring, storing and processing of appropriate information (Альбеков, Федько, Митько 2001, p. 512; Гуторов, Лебединська, Прозорова 2011, p. 322; Brzozowska, Bubel, Kalinichenko 2015, pp. 29-35). This definition is the most common in economic literature. It gives a rather clear understanding of the functional sphere of logistics by dividing the total tangible flow process into stages and it makes managerial functions of logistics more specific. However, this definition does not describe the possibility of application of logistics in optimization of management of finance flow which accompanies tangible flow. Moreover, only transportation and storage are not the full list of all processes included into logistics.

At the same time, logistics is considered to be not only a science but also a process. For instance, this opinion is given by I. Krykavskyi, N. Chukhrai and N. Chornopyska. They define logistics as the process of management of sufficient and effective (concerning time consumption) flow of raw materials supply, materials, semi-finished and finished products, services, finance and corresponding information from the place of appearance of this flow to the place of its consumption (including reception, dispatch, internal and external transfer) in order to meet all customer's requirements (Крикавський, Чухрай, Чорнописька 2006, p. 340). However, the possibility of full-fledged management of materials in external environment contradicts market economy conditions. On the base of this fact we think that the given above definition is also not very complete.

So, despite various approaches to defining logistics, the semantic analysis of the given definitions has enabled us to find their similarity. For instance, all scientists define its object as the movement of flows and optimization of links relations. Taking this and other critical statements into account we define logistics as the science about management of tangible and appropriate information and finance flows and their optimization within economic system where they occur from the moment of their appearance to the final consumption with the purpose to satisfy the final customer's needs.

Most researchers think that the objective of logistics is to follow "six logistics rules", such as: to produce the needed product of appropriate quality and in necessary amount and deliver it to a certain place at required time with minimum expenses (Крикавський, Чухрай, Чорнописька 2006, p. 340; Тридід, Азаренкова, Мішина, Борисенко 2008, p. 566; Гурч 2008, р. 560; Логістика: опорний конспект лекцій для напряму 0502 «Менеджмент» 2010, p. 116). So, logistics is aimed at the optimization of demand oriented production by means of efficient organization of flow processes which can provide the highest profitability in specific conditions of a certain economic system.

The main attention in logistics is focused on the organization of the sole through flow of transfer of materials and information from a producer to a customer. This requires making the sole integrated system which will unite the processes of materials and machinery supply, production, storage, selling, transporting as well as processing and transfer of appropriate information. This shift of priorities of 
economic activity - from product to flow process - is the novelty of the logistic approach which can raise the efficiency of work on each stage of promotion chain, improve internal economic links and result in synergic effect.

In economic literature logistics is subdivided into such interrelated parts as supply, production, selling and transport logistics (Скоробогатова 2005, p. 116). In addition to it some researchers add storage, intermediary and information logistics to the above mentioned list. The fullest description of functional spheres of logistics is given by O. Ieltenko. He defines logistics in supply, transport, storage, service, purchase, selling, production, information, finance and management (Слтенко 2008, pp.135-141). On the base of all these classifications and with the help of functional approach we can define the main subdivisions of logistics corresponding to the main stages of flows in business, such as purchase, production and selling (figure 1).

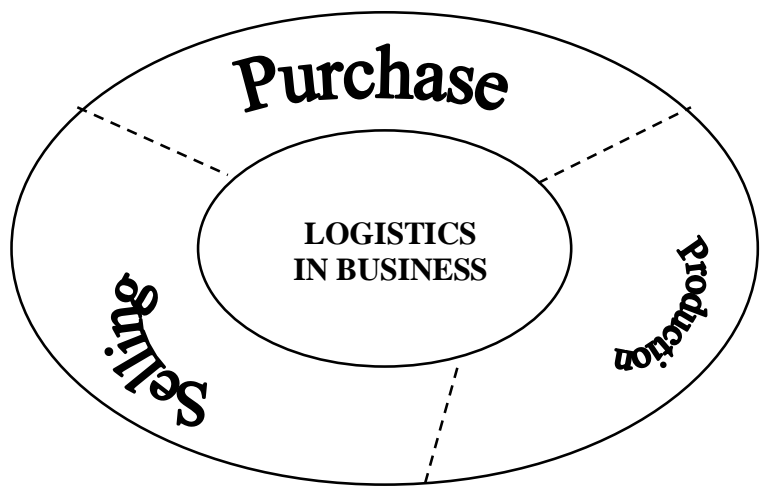

Figure 1. The main functional spheres of logistics in business

Source: worked out by the authors

However, it is necessary to mention that this subdivision is quite relative, as the stages of economic activity are interrelated and this results in the interrelation and interdependence of logistics tasks on each stage (Нікітіна 2013, pp. 132-133). For example, in order to determine the volume of purchase of necessary raw materials, their quality and term of purchase, it is necessary to take into account the productive capacity of a business, some peculiarities of its economic activity and development strategy. The latter one is in some way caused by customers' wants which should be taken into account in determining commodities range in order to improve production and selling processes.

According to some peculiarities of economic system tangible flow has its own form on each stage of movement and logistics has its object and specific tasks (table 1).

So, logistics makes it possible to solve a number of problems of economic activity of agrarian businesses. Its application provides a great potential to raise competitiveness of domestic agrarian products as in market conditions it enables businesses to evaluate and satisfy the customers' needs more fully. 
Table 1. Logistics tasks in agrarian businesses

\begin{tabular}{|c|c|c|}
\hline $\begin{array}{c}\text { Stage of movement } \\
\text { of tangible flow }\end{array}$ & $\begin{array}{c}\text { Form of tangible } \\
\text { flow }\end{array}$ & Logistics tasks \\
\hline Purchase & $\begin{array}{l}\text { Seeds, feeds, } \\
\text { seedlings, fuel and oil } \\
\text { materials, means of } \\
\text { protection of plants } \\
\text { and animals, } \\
\text { inventory, equipment, } \\
\text { machinery, and other } \\
\text { materials }\end{array}$ & $\begin{array}{l}\text { 1) improving of purchase of production goods needed } \\
\text { for manufacturing process according to agrarian and } \\
\text { technical requirements, technological cards and } \\
\text { development plans; } \\
\text { 2) determining of methods to organize purchase; } \\
\text { 3) organization of quality control of purchased } \\
\text { products; } \\
\text { 4) working out of a mechanism of selection of } \\
\text { suppliers }\end{array}$ \\
\hline Production & $\begin{array}{l}\text { Productive livestock, } \\
\text { growing and fattening } \\
\text { animals, perennial } \\
\text { plants and all kinds of } \\
\text { crops }\end{array}$ & $\begin{array}{l}\text { 1) solving problems of optimization of business size; } \\
\text { 2) determining the necessity and structure of a } \\
\text { machinery park and formation of its rational structure; } \\
\text { 3) determining the need for raw materials; } \\
\text { 4) organization of efficient use of production goods; } \\
\text { 5) providing of technical support of machinery, } \\
\text { buildings and equipment }\end{array}$ \\
\hline Selling & $\begin{array}{l}\text { Milk, eggs, grain, } \\
\text { vegetables, fruit and } \\
\text { other products }\end{array}$ & $\begin{array}{l}\text { 1) determining of selling strategy; } \\
\text { 2) selection of the structure of logistics chain; } \\
\text { 3) decisions making concerning forms and technology } \\
\text { of transportation of agrarian products and selection of } \\
\text { dispatch tactics; } \\
\text { 4) determining the necessity of establishment of } \\
\text { collective food markets of agrarian products. }\end{array}$ \\
\hline
\end{tabular}

Source: Worked out by the authors on the base of (Божидарнік, Божидарнік 2011, pp. 27-31; Струк 2009).

Oversaturation of a market, which is proved by works of national and domestic researches, needs reorientation of business from production to distribution and this fact focuses on selling logistics and marketing as priorities. It is necessary to apply both conceptions because their functions are quite different although both improve selling process aimed at satisfying customers' wants. For instance, the marketing conception researches the market and evaluates the demand while logistics provides transportation of goods and satisfaction of the demand with minimal expenses (Лужин 2011, pp. 22-23). Their objects, subjects and conclusions also differ (table 2).

However, the systems of marketing and logistics are closely connected to each other which can be proved by the similarity of their certain elements. For instance, the closest relation between logistics and marketing can be found in the provision of the availability of a necessary product at an appropriate place. The other elements (quantity, quality, time, expenses and consumer - from logistics side and price, package, people and promotion - from marketing side) do not have a direct connection though they are also interrelated and interdependent. Thus, optimization of selling activity requires introduction of both logistics and marketing mechanisms. 
Table 2. Distinctive features of marketing and logistics

\begin{tabular}{|l|l|l|}
\hline Compared features & \multicolumn{1}{|c|}{ Marketing } & \multicolumn{1}{c|}{ Logistics } \\
\hline $\begin{array}{l}\text { The object of the } \\
\text { research }\end{array}$ & Market, demand, supply & Tangible flow \\
\hline $\begin{array}{l}\text { The subject of the } \\
\text { research }\end{array}$ & Behaviour on a market & Tangible flow management \\
\hline $\begin{array}{l}\text { The result of the } \\
\text { research }\end{array}$ & $\begin{array}{l}\text { Range of products, their } \\
\text { sales markets, means to } \\
\text { stimulate demand }\end{array}$ & $\begin{array}{l}\text { Location of warehouses, } \\
\text { transportation schemes, } \\
\text { consignments, term of selling, } \\
\text { chain of goods flow }\end{array}$ \\
\hline
\end{tabular}

Source: Worked out by authors on the base of (Репич 2008, pp. 86-89).

Agriculture has its own specific features, for instance, the products of this branch are the base of food which makes the loss of demand for it impossible. Accordingly, the need to stimulate sales is not so urgent and that is why marketing becomes not very efficient and significant in this sphere. Although the specific features of agrarian products exclude the possibility of their overproduction in global aspect and their relatively short storage life causes the necessity for an elaborated and efficient system of selling these products. At the same time a long flow of goods from a producer to a final consumer results in raising prices for agrarian products which makes them less attractive in terms of low paying capacity, nevertheless, these goods are sufficient in consumer's basket. Thus, the all above mentioned problems, which finally result in aggravation of food security on the one hand and in cutting profits of agrarian businesses on the other hand, require the introduction of logistic approaches into selling activity.

Agrarian logistics is on the stage of its formation and we consider its further development as its subdivision into logistic spheres according to specific features of agrarian products. For instance, it is necessary to subdivide national agrarian logistics into such spheres as, crop growing, livestock breeding, fishing and bee keeping logistics with a detailed classification of branches according to the main types of products (figure 2).

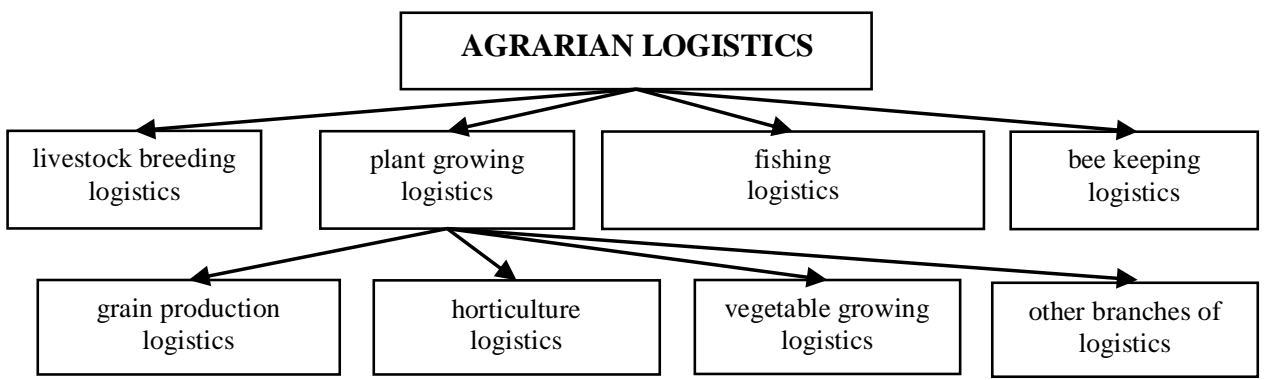

Figure 2. The system of agrarian logistics

Source: Worked out by the authors. 
The necessity of introduction of logistics into Ukrainian agriculture is also considered by D. Krysanov. For instance, he points out that the establishment of flexible logistics systems will make the process of formation of consignments of goods quicker; it will also facilitate the delivery of products to necessary places with minimal expenses and provide competitive advantages (Крисанов 2010, pp. 39-41). Moreover, the competitiveness of businesses using logistic approach is provided by the means of cost reduction and improvement of reliability and quality of delivery. While establishing the selling logistics system in business it is necessary to take into account a number of internal and external factors assisting in its adaptation to certain specific features of business, market conditions and customers' needs (figure 3 ).

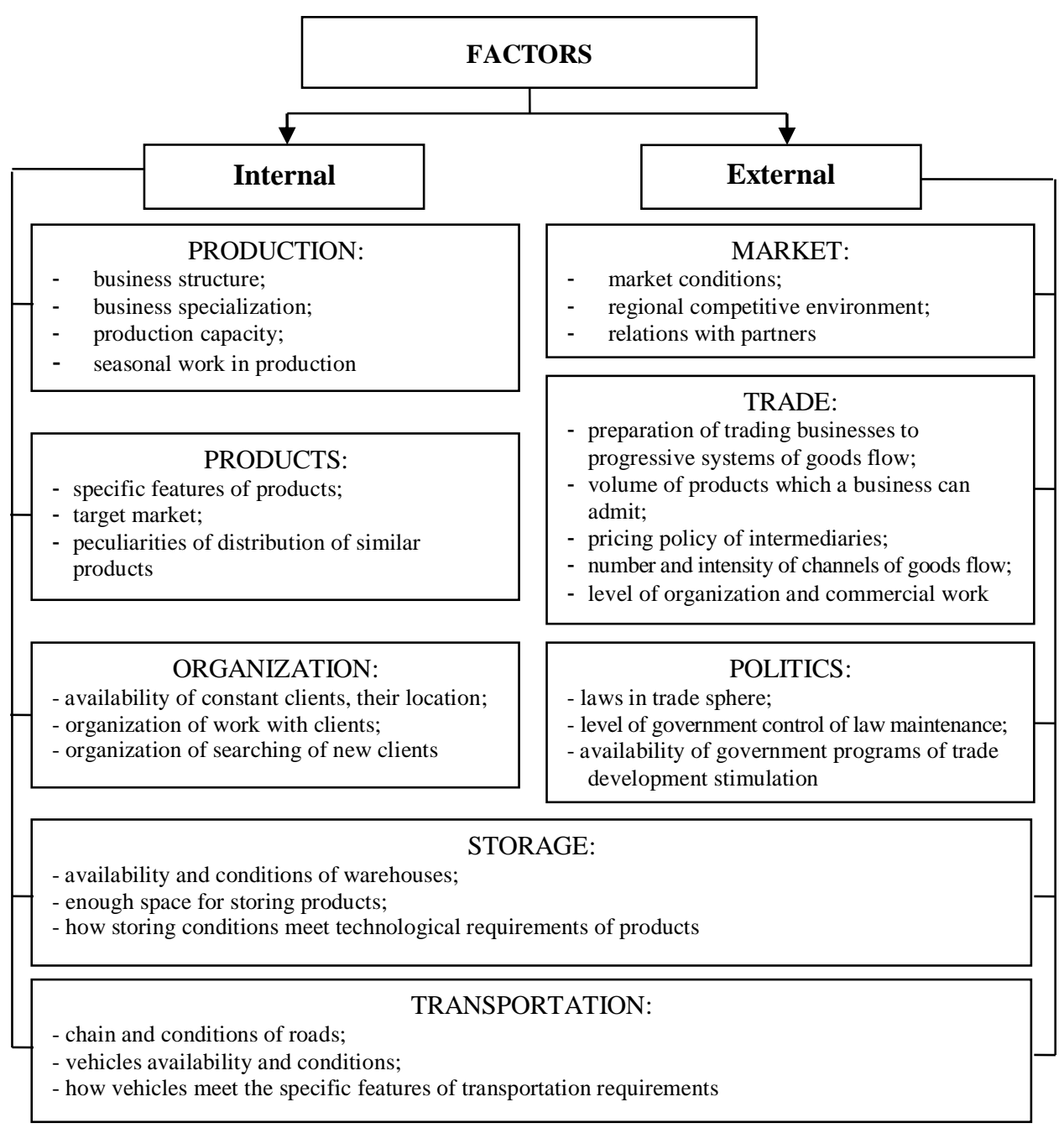

Figure 3. Factors affecting the system of logistics in selling process in agriculture

Source: Worked out by authors on the basis of: Тридід, Азаренкова, Мішина, Борисенко 2008, p.566; Кислий, Біловодська, Олефіренко, Смоляник 2010, р. 360. 
It is necessary to point out that the subdivision of logistics into spheres on the base of livestock breeding branches (cattle breeding, pig fattening and poultry farming) is rather difficult which is caused by the lack of fundamental organization and technology differences between them as well as by the orientation of their products to the same markets and meeting the similar customers' requirements.

At the same time this system can be supplemented with other types of logistics which will develop on the base of domestic agriculture and will have their own specific features affecting their management.

It is obvious that the present situation expects from agrarian sector not only high quality products but also solving the new types of problems such as: when, where and in what amount it is necessary to supply goods to customers with minimum expenses. This has become the stimulus to the development of agrarian logistics.

Nowadays there are some barriers to efficient functioning of agrarian logistics such as:

- the lack of state programs of development of agrarian logistics;

- the low investment attractiveness of agrarian branches in Ukraine which is caused by inefficient legal framework and unstable political situation in the country;

- the lack of automobile and railroad transport in peak periods of agrarian campaigns;

- the lack of funds for building modern warehouses;

- the delays of payments to agrarian transporters;

- the delays in service of agrarian transporters;

- the lack of highly qualified logistic staff in agrarian businesses;

- the delays in delivery of products;

- the wear of vehicles and difficulties in their updating;

- the lack of funds for the purchase of modern vehicles;

- the fluctuations in transport tariffs;

- the decrease in competitiveness of Ukrainian transporters compared to the foreign ones;

- the lack of funds for introduction of logistics approaches as logistics software is too expensive for national businesses;

- the failure in provision of transport to be loaded at agreed dates;

- the difficulties in working out transport routes;

- the poor quality of roads, inefficient digital software GPS-provision of Ukrainian roads and the lack of communication networks for trucks;

- the difficulties in organization of transportation including several kinds of transport;

- the insurance of loads and vehicles;

- the unpredictable risks connected with climatic changes.

In addition to these barriers, it is necessary to mention some ways of the improvement of the system of agrarian logistics such as: reforms in agrarian sector and the establishment of appropriate legal framework in regulation of activities of 
agrarian logistic companies; the adoption of the national program of the development of agrarian logistic according to the examples of advanced countries; the development and introduction of the appropriate system of financing of agrarian logistics; the raising of investment attractiveness of logistic sector by the means of using special regimes in taxation and reduced customs tariffs for limited periods (1-3 years); the provision of this branch with highly qualified staff and necessary software, etc.

\section{Conclusions}

For the last several years national agrarian businesses have begun to take into account the fact that the sphere of supplying raw materials and services has a great impact on the ability of economic entities to satisfy customers' needs.

Thus, the introduction of logistics into business has a large potential for the improvement of selling, promotion of innovation activities and raising the competitiveness of agrarian enterprises.

The use of logistic approaches in the management of Ukrainian enterprises and the management of supplies is a relatively new direction; moreover these approaches are still being formed in agriculture.

The urgency of introduction of logistics into the activities of national agrarian enterprises can be explained by the need for reducing the intervals between supplying raw materials and delivery of products to final customers. Logistics enables enterprises to minimize stock of goods and in several cases even to refuse it, as well as to reduce delivery time, facilitate the process of receiving information, and improve the quality of service.

\section{References}

1. Brzozowska A., Bubel D., Kalinichenko A., Tendencies in financing the agricultural and food sector under the common agricultural policy. J. Socio-Economic problem and the State [online], 2015, Vol. 13, No. 2, pp. 29-35.

2. Альбеков А.У., Федько В.П., Митько О. А., Логистика коммерции: [учебн.].Ростов-на-Дону: Феникс, 2001, р. 512.

3. Божидарнік Т. В., Божидарнік Н. В., Основні шлляхи застосування логістики в агропромисловому комплексі України // Економічний форум. - 2011. - №1, pp. 27-31.

4. Гурч Л. М. Логістика: [навч. посіб.] . -К.: Персонал, 2008, p. 560.

5. Гуторов О.І., Лебединська О.І., Прозорова Н.В., Логістика: навч. посіб. // Харк. нац. аграр. ун-т. - Харків: Міськдрук, 2011, р. 322.

6. Слтенко О.В. Проблеми сучасної логістики та шляхи їх вирімення // Актуальні проблеми економіки. - 2008. - № 4, pp.135-141.

7. Кислий В. М., Біловодська О. А., Олефіренко О. М., Смоляник О. М., Логістика: Теорія та практика: [навч. посіб.]. - К.: ЦУЛ, 2010, р. 360.

8. Косарева Т. В. Логістична система: сутність дефініиій // Економіка АПК. - 2008. № 11, pp. 12-19.

9. Крикавський Є. В., Чухрай Н. І., Чорнописька Н. В., Логістика: компендіум і практикум: [навч. посіб.]. - К.: Кондор, 2006, p. 340.

10. Крикавський Є. В., Чухрай Н. І., Чорнописька Н. В., Логістика: компендіум і практикум: навч. посіб. - К.: Кондор, 2006, р. 340. 
11. Крисанов Д.Ф. Передумови та чиники впровадження логістичних інновацій в агропродовольчому комплексі України // Економіст. - 2010. - № 12, pp. 39-41.

12. Логістика: опорний конспект лекцій для напряму 0502 «Менеджмент» [Електронний ресурс] / уклад. С. О. Казаков. - Електрон. текст. дані. - Миколаїв: МДАУ, 2010, p. 116 Режим доступу: libserver.mdau.mk.ua /docs/eldocs /2010/Kazakov_Logistika.pdf.

13. Лужин А.Л. Логистика и маркетинг: точки соприкосновения // Молочное дело. 2011. - № 7, pp. 22-23.

14. Нікітіна Р. С. Логістика як інструмент удосконалення збутової діяльності сільськогосподарських підприємств // Менеджмент і логістика - перспективні напрями розвитку економіки: Матеріали Міжнародної науково-практичної конференції: тези допов. - Київ. - 20-21 вересня 2013, pp. 132-133.

15. Репич Т.А. Маркетинг и логистика. Что важнее? // Мясной бизнес. - 2008. - №5, pp. 86-89.

16. Родников А.Н., Логистика: терминологический словар: [2-е изд., испр. и доп.] - М.: ИНФРА-М, 2000, p. 352.

17. Скоробогатова Т.Н. Логистика: [учеб. пособ. ; 2-е изд.]. - Симферополь: ДиАйПи, 2005, p. 116.

18. Струк Н. Р. Напрями застосування логістики у підприємствах аграрного сектору економіки [Електронний ресурс] - Режим доступу: archive.nbuv.gov.ua/portal/chem_biol/ vldau/APK/2009/ files/09snxsoe.pdf.

19. Тридід О. М., Азаренкова Г. М., Мішина С. В., Борисенко I. І., Логістика: [навч. посіб.] - К.: Знання, 2008, р. 566.

20. Тридід О. М., Азаренкова Г. М., Мішина С. В., Борисенко І. І., Логістика: [навч. посіб.]. - К.: Знання, 2008, р.566.

\section{SYSTEM LOGISTYKI ROLNEJ: DEFINICJA, GŁÓWNE ZADANIA I WARUNKI FUNKCJONOWANIA}

Streszczenie: W opracowaniu zbadano istotę terminu „logistyka” i podano jego najpełniejszą definicję. Uzasadniono główne obszary funkcjonowania oraz zadania logistyki przedsiębiorstw rolnych. Określono charakterystyczne cechy badań marketingowych i logistyki, jak również realność ich wdrożenia w celu optymalizacji działań marketingowych. Zaprezentowano system logistyki rolniczej, w tym logistyki upraw, żywego inwentarza, hodowli ryb oraz pszczelarstwa, a następnie wyszczególniono branże ze względu na główne produkty. Ukazano czynniki wpływu na system procesu wdrażania logistyki w sektorze rolniczym w celu adaptacji do specyfiki przedsiębiorstwa rolnego.

Słowa kluczowe: logistyka, wdrożenie, zarządzanie, przedsiębiorstwo rolnicze, zaopatrzenie, sprzedaż, produkcja 